\title{
Effects of different processing methods of Napoleona imperialis (Napoleons Hat) on haematology and serum biochemistry of finisher broiler
}

${ }^{1}$ Urom, S. M. O. C., ${ }^{2}$ Ukpabi, U. H., ${ }^{* 1}$ Onunkwo, D. N., ${ }^{1}$ Abu, E. B. and ${ }^{2}$ Nweke, J. O. ${ }^{l}$ College of Animal Science and Animal Production, Michael Okpara University of Agriculture, Umudike, Abia State Nigeria.

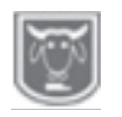

Abstract

${ }^{2}$ Department of Animal Science and Fisheries, Faculty of Agriculture, Abia State University, Uturu, Nigeria.

Four weeks feeding trial involving 120 (one hundred and twenty) Fedan finisher broilers was carried out in a completely randomized design. The birds were divided into five treatment groups of 24 birds per treatment, represented as T1, T2, T3, T4 and T5 respectively, and replicated into 3 of 8 birds per replicate. Water and feed were given ad-libitum.T1 had no Napoleon's hat seed meal and served as the control,T2 had raw NISM,T3 had 30 minutes boiled NISM,T4 had 60 minutes NISM, while T5 had 90 minutes boiled NISM. The result of the study showed significant differences $(p<0.05)$ in all the parameters measured except Basophil, Monocytes and white blood cell. There were also significant differences among the biochemical parameters beside cholesterol, albumin, alkaline phosphate (ALP) and aspartate $T_{5}$ 10.05, while Aspartate transaminase (AST). Packed cell volume PCV (\%) recorded the highest value of $34.35 \%$ in Treatment $5 T_{5)}(34.35 \%)$, (90 minutes, while the lowest value (33.30) was recorded in $T_{3} 33.30$, (30 minutes of boiling) Treatment $4\left(T_{4}\right)$ recorded the highest value of $10.80 \mathrm{~g} / \mathrm{dL}$ in $\mathrm{Hb}$, while the lowest value was recorded $T_{5}$ (10.05), while for $W B C$, the highest value of $248.67 \times 103 / \mu l$ was recorded in $T_{3} W B C$ and lowest value of 244.07 was recorded in $T_{4}(60$ minutes). Urea level reduced with increase in heat treatment, from 4.00 in $T_{4}$ to $6.70 \mathrm{mg} / \mathrm{dL}$ in $T_{3}$, creatinine $(\mathrm{mg} / \mathrm{dL})$ and total protein

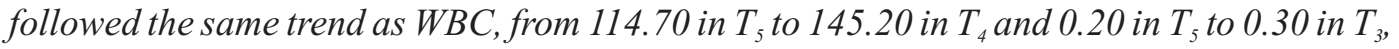
respectively. The result suggests that $10 \%$ inclusion of Napoleona imperialis seed meal could be used in broiler feed successful without deleterious.

Keywords: Processing methods, Napoleona imperialis, biochemical parameters, boiling

\section{Introduction}

The poultry industry in Nigeria has been greatly affected by high cost of feed. The provision of feed alone has been reported to account to $60-80 \%$ of the total cost in most livestock production in developing countries, such as Nigeria (Esonu, 2000; Igboeli, 2000). In view of this, there is increase by Nigerian livestock farmers to harness unconventional feed ingredients such as meals of tropical legumes, shrubs and trees that are readily available but not competed for in man's dietary needs.

The persistent decline in the poultry industry and its consequences on the suboptimal animal protein consumption by Nigerians is a dangerous signal to imminent animal protein malnutrition. Esonu (2002) stated that more than 50\% of the country poultry farmers has closed down and another $30 \%$ forced to reduce their production capacity because of shortage of feeds. This feed shortage has been blamed on high cost of conventional sources of ingredients which Opara (1996); Madubuike and Ekenye (2001) have observed at $70-80 \%$ of total cost of poultry production. The current trend in the cost of 


\section{Processing methods of Napoleona imperialis (Napoleons Hat)}

feed and as well as irregular supply of feed (Uko and Kamalu, 2008) poses a threat to the future of livestock and poultry industry (Soaiya, 1990). The cost of feed alone represents approximately $75 \%$ of the cost of poultry production. It therefore becomes imperative to intensify efforts in the search for cheaper, abundant and locally available alternatives that have no direct dietary value to man, for sustainable production (Odunsi, 2002). There is need to look for locally available and cheap source of feed ingredients particularly those that do not attract competition between man and livestock like Napoleona imperalis seed meal (Uchegbu et al., 2002). There is therefore the need to investigate the effects of these unconventional feed resources on the physiological status of the animal, especially the haematology. The fruit sugary pulp is used as deserts, the root for medicinal purpose and the twigs as traditional chew sticks. A form of redish seed of this species constitutes a false kola, which has a taste of real kola. Uchegbu et al. (2004), reported a decline in the performance of broiler with increase in inclusion level of raw NISM which suggest the presence of anti nutritional factor in raw NISM as reported in some unconventional feed stuff (Udedibie and Carlini, 1998). Therefore NISM, if well processed can become a likely feed resource for poultry.

\section{Materials and methods}

The study was carried out at the poultry unit of Abia State University, Umudike Abia state, Nigeria. Umudike bears the coordinate of five degrees $\left(5^{0}\right) 28$ minutes North and $7^{\circ}$ South and lies at an altitude of $122 \mathrm{~m}$ above sea level. It is located within the tropical rainforest zone and the environment is characterized by an annual rainfall of $2177 \mathrm{~mm}$. the relative humidity during rainy season is well above $72 \%$, mostly ambient temperature ranges between 22-30 $\mathrm{C}$ (NRCRI, 2010).

Ripe Napoleona imperialis (Napoleon's Hat) fruits were harvested at Umudike location of Abia State University Umuahia Campus, Abia state, Nigeria (Latitude $5^{0}$, Longitude $7^{0} \mathrm{E}$ ). The pods were opened with a knife, the seeds extracted and then sun-dried for about seven (7) days when the moisture content was reduced depending on the weather at the period of experiment.. A portion of the sun-dried $N$. imperialis seed was milled using hammer mill to produce the raw $N$. imperialis seed meal (NISM). While the remaining portions were cooked in water for 30 minutes, 60 minutes and 90 minutes, then sun-dried before milling to produce boiled and dried NISM. Five experimental diets were formulated with $0.00 \%$ and $10 \%$ raw, $10 \%$ and 30 minutes boiled, $10 \%$ of $N$. imperialis seed meal boiled for 60 minutes boiled and $10 \%$ of $N$. imperialis seed meal boiled for 90 minutes and boiled $N$. imperialis seed meal which were designated $\mathrm{T}_{1}, \mathrm{~T}_{2}, \mathrm{~T}_{3}, \mathrm{~T}_{4}$ and $\mathrm{T}_{5}$, respectively. A total number of one hundred and twenty Fedan finisher broilers were randomly assigned to the five (5) dietary treatments, ( $\mathrm{T}_{1}$ - control, $\mathrm{T}_{2}, \mathrm{~T}_{3}, \mathrm{~T}_{4}, \mathrm{~T}_{5}$ ) of 24birds per treatment, which were further replicated into 3 per treatment giving 8 birds per replicate. Feed and water were given $a d-$ libitum for the period of the experiment.

The five experimental diets as presented in Table I were formulated in such a way that diet I (control) had no NISM, while diet $\mathrm{T}_{2}$ (Raw), $\mathrm{T}_{3}$ (30mins), $\mathrm{T}_{4}$ (60mins) and $\mathrm{T}_{5}$ (90mins) contained 10\% NISM each which replaced $\mathrm{PKC}$ in the diet.

The experiment was conducted in a completely randomized design (CRD) as outlined in Clarke (1982). The model is represented below: 


\begin{tabular}{|c|c|c|c|c|}
\hline$Y_{\mathrm{ij}} \quad=$ & $\mathrm{U}+\mathrm{T}_{\mathrm{i}}+\mathrm{e}_{\mathrm{ij}}$ & $\mathrm{U}$ & $=$ & overall mean \\
\hline Where; & & $\mathrm{Ti}$ & $=$ & Effect of $i^{\text {th }}$ treatment \\
\hline $\begin{array}{l}\mathrm{Y}_{\mathrm{ij}} \quad= \\
\mathrm{i}^{\text {th }} \text { treatmen }\end{array}$ & $i^{\text {th }}$ observation made on the & $\mathrm{E}_{\mathrm{ij}}$ & $=$ & Experimental error \\
\hline
\end{tabular}

Table 1: Composition of experimental diets (\%)

\begin{tabular}{llllll}
\hline Feed ingredients & T1 & T2 & $\begin{array}{l}\text { T3 } \\
\text { Boiled }\end{array}$ & T4 & T5 \\
\hline Maize grain & 54.00 & 54.00 & 54.00 & 54.00 & 54.00 \\
SBM & 28.00 & 28.00 & 28.00 & 28.00 & 28.00 \\
Fish meal & 4.00 & 4.00 & 4.00 & 4.00 & 4.00 \\
NISM & 0.00 & 10.00 & 10.00 & 10.00 & 10.00 \\
PKC & 10.00 & 0.00 & 0.00 & 0.00 & 0.00 \\
Bone meal & 3.00 & 3.00 & 3.00 & 3.00 & 3.00 \\
Vitamin premix & 0.25 & 0.25 & 0.25 & 0.25 & 0.25 \\
Methionine & 0.25 & 0.25 & 0.25 & 0.25 & 0.25 \\
Salt & 0.25 & 0.25 & 0.25 & 0.25 & 0.25 \\
Lysine & 0.25 & 0.25 & 0.25 & 0.25 & 0.25 \\
Total & 100 & 100 & 100 & 100 & 100 \\
\hline
\end{tabular}

Table 2: Proximate composition of pod, raw and boiled Napoleona imperialis seed meal

\begin{tabular}{|c|c|c|c|c|c|c|}
\hline & & \multicolumn{5}{|c|}{ Boiled (minutes) } \\
\hline Parameters & Pod & Raw & 30 & 60 & 90 & SEM \\
\hline Dry matter & $91.19^{\mathrm{a}}$ & $90.55^{\mathrm{b}}$ & $89.94^{c}$ & $90.12^{\mathrm{c}}$ & $90.10^{c}$ & 0.066 \\
\hline Ash & $6.82^{\mathrm{a}}$ & $4.86^{\mathrm{c}}$ & $5.25^{\mathrm{b}}$ & $4.28^{\mathrm{e}}$ & $4.63^{\mathrm{d}}$ & 0.026 \\
\hline Crude fiber & $9.30^{\mathrm{a}}$ & $7.23^{\mathrm{b}}$ & $6.87^{\mathrm{c}}$ & $6.70^{\mathrm{d}}$ & $6.46^{\mathrm{e}}$ & 0.026 \\
\hline Ether extract & $8.60^{\mathrm{a}}$ & $6.26^{\mathrm{b}}$ & $5.71^{\mathrm{c}}$ & $5.67^{\mathrm{c}}$ & $5.51^{\mathrm{d}}$ & 0.041 \\
\hline Crude protein & $19.84^{\mathrm{c}}$ & $21.88^{\mathrm{a}}$ & $20.38^{\mathrm{b}}$ & $19.56^{\mathrm{d}}$ & $18.74^{\mathrm{e}}$ & 0.075 \\
\hline NFE & $46.63^{\mathrm{e}}$ & $50.32^{\mathrm{d}}$ & $51.73^{c}$ & $53.91^{\mathrm{b}}$ & $54.74^{\mathrm{a}}$ & 0.10 \\
\hline
\end{tabular}

abcde means on the same row with different superscripts differed significantly $(\mathrm{P}<0.05)$

SEM - standard error of mean

NFE - Nitrogen free extract

At the end of the experiment, two birds from each of the three replicates were selected for blood samples. About two (2) $\mathrm{ml}$ of blood sample were collected into labelled sterile universal bottles containing a drop of EDTA (Ethylene Diamine Tetraacetic Acid) to determine the haematological indices such as packed cell volume (PCV), white blood cell (WBC), Red blood cell (RBC), haemoglobin (Hb). A second sample, $8 \mathrm{ml}$ was collected with a sterile labeled syringe without EDTA and then allowed to coagulate to determine the biochemical indices such as creatinine, urea, glucose, alkaline phosphate (ALP), total protein serum, albumin and globulin.

\section{Results and discussion}

The result of haematological indices as shown in Table 3 shows that PVC(\%), $\mathrm{Hb}(\mathrm{g} / \mathrm{dl}), \mathrm{RBC}\left(\mathrm{x} 10^{6} / \mu / \mathrm{L}\right)$ increase as the level of heat increase while white blood cell WBC did not show any significant difference $(p>0.05)$ as the level of heat increased. There were significant differences $(\mathrm{P}<0.05)$ in Basophils $(\%)$ and Monocytes $(\%)$ with the increase in heat treatment. 
Processing methods of Napoleona imperialis (Napoleons Hat)

Table 3 : Haematological values finisher broilers fed diet containing raw and boiled

Napoleanaimperialis seed meal

\begin{tabular}{|c|c|c|c|c|c|c|}
\hline \multicolumn{7}{|c|}{ Boiled (minutes) } \\
\hline & $\mathbf{T}_{1}$ & $\mathbf{T}_{2}$ & $\mathbf{T}_{3}$ & $\mathbf{T}_{4}$ & $\mathbf{T}_{5}$ & SEM \\
\hline Parameters & Controls & Raw & 30 & 60 & 90 & \\
\hline PVC (\%) & $33.80^{\mathrm{b}}$ & $32.33^{\mathrm{c}}$ & $33.30^{\mathrm{b}}$ & $32.70^{\mathrm{c}}$ & $34.35^{\mathrm{a}}$ & 0.16 \\
\hline $\mathrm{Hb}(\mathrm{g} / \mathrm{dl})$ & $10.20^{\mathrm{c}}$ & $9.80^{\mathrm{d}}$ & $10.50^{\mathrm{b}}$ & $10,80^{\mathrm{a}}$ & $10.05^{\mathrm{c}}$ & 0.073 \\
\hline $\mathrm{RBC}(\mathrm{x} 106 / \mu / \mathrm{L})$ & $2.34^{\mathrm{b}}$ & $2.41^{\mathrm{a}}$ & $2.39^{\mathrm{a}}$ & $2.38^{\mathrm{a}}$ & $2.36^{\mathrm{a}}$ & 0.018 \\
\hline $\mathrm{WBC}(\mathrm{x} 103 / \mu / \mathrm{L})$ & $247.23^{\mathrm{a}}$ & $248.27^{\mathrm{a}}$ & $248.67^{\mathrm{b}}$ & $244.07^{\mathrm{b}}$ & $247.53^{\mathrm{a}}$ & 0.48 \\
\hline Neutrophils (\%) & $18.79^{c}$ & $25.60^{\mathrm{ab}}$ & $16.44^{\mathrm{d}}$ & $26.60^{\mathrm{a}}$ & $25.68^{b}$ & 0.14 \\
\hline Lymphocytes (\%) & $68.60^{\mathrm{b}}$ & $61.80^{c}$ & $70.80_{\mathrm{a}}$ & $60.50^{\mathrm{d}}$ & $61.70^{\mathrm{c}}$ & 0.010 \\
\hline Eosinophils (\%) & $7.41^{\mathrm{b}}$ & $7.30^{\mathrm{c}}$ & $7.56^{\mathrm{a}}$ & $7.50^{\mathrm{ab}}$ & $7.32^{\mathrm{c}}$ & 0.036 \\
\hline Basophils (\%) & $5.00^{\mathrm{a}}$ & $5.10^{\mathrm{a}}$ & $5.00^{\mathrm{a}}$ & $5.20^{\mathrm{a}}$ & $5.10^{\mathrm{a}}$ & 0.061 \\
\hline Monocytes (\%) & $0.20^{\mathrm{a}}$ & $0.20^{\mathrm{a}}$ & $0.20^{\mathrm{a}}$ & $0.20^{\mathrm{a}}$ & $0.20^{\mathrm{a}}$ & 0.00 \\
\hline $\operatorname{MCV}(\mathrm{fl})$ & $143.70^{\mathrm{a}}$ & $135.80^{\mathrm{c}}$ & $141.20^{\mathrm{b}}$ & $137.40^{\mathrm{d}}$ & $139.70^{\mathrm{c}}$ & 0.39 \\
\hline $\mathrm{MCH}(\mathrm{pg})$ & $43.00^{\mathrm{a}}$ & $42.50^{\mathrm{ab}}$ & $42,00^{\mathrm{b}}$ & $40.20^{\mathrm{d}}$ & $41.70^{c}$ & 0.24 \\
\hline $\mathrm{MCHC}(\mathrm{g} / \mathrm{dl})$ & $29.00^{\mathrm{c}}$ & $30.60^{\mathrm{b}}$ & $31.80^{\mathrm{ab}}$ & $29.50^{\mathrm{c}}$ & $33.10^{\mathrm{a}}$ & 0.49 \\
\hline
\end{tabular}

Results for packed cell volume (PCV) were $33.8,32.33,33.30,32.70$ and $34.35 \%$ for $\mathrm{T}_{1}$, $\mathrm{T}_{2}, \mathrm{~T}_{3}, \mathrm{~T}_{4}$ and $\mathrm{T}_{5}$, respectively. Ninety (90) minutes boiled Napoleona imperialis $\left(\mathrm{T}_{5}\right)$ seed meal recorded the highest value of PVC. The values obtained in PVC were within normal range of $22-35 \%$ as reported by (Jain, 1993) for birds. Inclusion of Napoleona imperialis seed meal in the diet of finisher broiler tended to improve their haematological competence of broilers especially at $10 \%$ dietary level. Haematological values are indirect pointers to the health of livestock (Jain, 1993; Kecceci et al., 1998; Jain, 1993). Haemoglobin $(\mathrm{Hbg} / \mathrm{dl})$ concentration of finisher broiler fed diet containing boiled
NISM indicate the following value 10.2, $9.8,10.5,10.8$ and $10.05,60$ minutes boiled Napoleona imperialis seed meal recorded the highest value in $\mathrm{Hb}$. The results were within the normal range as recorded by Jain (1993), though with an increase in the inclusion levels of NISM, the values obtained decreased. A decrease in haemoglobin is an important determinant of anaemia. This may probably lead to reduction of $\mathrm{O}_{2}$ carrying capacity of blood in the specie with reduction in performance. This result is in line with earlier study conducted by Ayodeji et al. (2005) who reported that the higher the inclusion of NISM in broiler chicken ration, the lower the $\mathrm{Hb}$ values.

Table 4: Serum biochemistry of finisher broilers fed diet containing raw and boiled Napoleanaimperialis seed meal

\begin{tabular}{lllllll}
\hline & \multicolumn{7}{c}{ Boiled (minutes) } & \multicolumn{1}{c}{} & \\
& $\mathbf{T}_{\mathbf{1}}$ & $\mathbf{T}_{\mathbf{2}}$ & $\mathbf{T}_{\mathbf{3}}$ & $\mathbf{T}_{\mathbf{4}}$ & $\mathbf{T}_{\mathbf{5}}$ & SEM \\
Parameters & Controls & Raw & $\mathbf{3 0}$ & $\mathbf{6 0}$ & $\mathbf{9 0}$ & \\
\hline Urea $(\mathrm{mg} / \mathrm{dl})$ & $3.70^{\mathrm{b}}$ & $7.30^{\mathrm{a}}$ & $6.70^{\mathrm{a}}$ & $4.00^{\mathrm{b}}$ & $4.67^{\mathrm{b}}$ & 0.54 \\
Creatinine $(\mathrm{mg} / \mathrm{dl})$ & $0.20^{\mathrm{b}}$ & $0.30^{\mathrm{a}}$ & $0.30 \mathrm{a}$ & $0.20 \mathrm{~b}$ & $0.20^{\mathrm{b}}$ & 0.018 \\
Glucose $(\mathrm{mg} / \mathrm{dl})$ & $218.33^{\mathrm{ab}}$ & $190.30^{\mathrm{b}}$ & $197.04^{\mathrm{b}}$ & $251.65^{\mathrm{a}}$ & $192.65^{\mathrm{b}}$ & 0.47 \\
Cholesterol $(\mathrm{mg} / \mathrm{dl})$ & $142.70^{\mathrm{a}}$ & $93.00^{\mathrm{a}}$ & $124.70^{\mathrm{a}}$ & $145.20^{\mathrm{a}}$ & $114.70^{\mathrm{a}}$ & 29.62 \\
Total protein $(\mathrm{g} / \mathrm{dl})$ & $3.15^{\mathrm{b}}$ & $4.90^{\mathrm{a}}$ & $3.60^{\mathrm{c}}$ & $3.15^{\mathrm{b}}$ & $2.80^{\mathrm{d}}$ & 0.26 \\
Globulin $(\mathrm{g} / \mathrm{dl})$ & $1.30^{\mathrm{a}}$ & $1.60^{\mathrm{a}}$ & $1.50^{\mathrm{a}}$ & $1.70^{\mathrm{a}}$ & $1.40^{\mathrm{a}}$ & 0.32 \\
Albumin $(\mathrm{g} / \mathrm{dl})$ & $1.85^{\mathrm{bc}}$ & $3.30^{\mathrm{a}}$ & $2.10^{\mathrm{b}}$ & $1.45^{\mathrm{c}}$ & $1.40^{\mathrm{c}}$ & 0.12 \\
AST $(\mu / \mathrm{L})$ & $89.00^{\mathrm{a}}$ & $89.00^{\mathrm{a}}$ & $89.00^{\mathrm{a}}$ & $89.00^{\mathrm{a}}$ & $89.00^{\mathrm{a}}$ & 0.00 \\
ALT $(\mu / \mathrm{L})$ & $10.30^{\mathrm{a}}$ & $3.0^{\mathrm{c}}$ & $3.30^{\mathrm{c}}$ & $4.43^{\mathrm{b}}$ & $4.30^{\mathrm{b}}$ & 0.30 \\
ALP $(\mu / \mathrm{L})$ & $615.70^{\mathrm{a}}$ & $557.30^{\mathrm{a}}$ & $462.30^{\mathrm{a}}$ & $645.30^{\mathrm{a}}$ & $652.30^{\mathrm{a}}$ & 146.92 \\
abc Means in the same row with different superscripts differed significantly $(\mathbf{P}<\mathbf{0 . 0 5})$ & & &
\end{tabular}


The serum biochemistry parameters of finisher broilers fed diets containing boiled Napoleonaimperialis seed meal is presented in table 3.

From the result, there were significant differences $(\mathrm{P}<0.05)$ in urea, creatinine, glucose, cholesterol and total protein, while Albumin, AST and ALP did not show any significant differences $(\mathrm{P}>0.05)$ urea recorded the highest value of 6.70 in $\mathrm{T}_{3}(30$ minutes heat) while the lowest value was recorded in $\mathrm{T}_{4}-4.00$ (60 minutes heat). Total protein levels reduced with the level of heat.Values recorded in total protein were $3.5,4.90,3.60,3.15$ and 2.80 for $\mathrm{T}_{1}$, $\mathrm{T}_{2}, \mathrm{~T}_{3}, \mathrm{~T}_{4}$ and $\mathrm{T}_{5}$, respectively. The values obtained in this work were below the normal values of 5 to $7 \mathrm{mg} / \mathrm{dl}$ reported by Banerjee (2007) for birds.Low serum total protein is an indication of the presence of poor quality protein in the diet and poor quality protein utilization (Fasina et al., 1990). Albumin followed the same trend as the total protein values falling below the normal range as recorded by Banerjee (2007). Low values of albumin results in poor blood clotting hence birds can be prone to haemorrhage.

\section{Conclusion}

The study shows that Napoleon imperialis seed meal (NISM) is a viable unconventional feedstuff that could be used in broilers' diet without health problems when well proceed and it is very good and cheap for livestock production.

\section{References}

Ayodeji, O. F., Kola, S. O. and Samuel, O. A. 2005. Nutritional potentials of siam weed (Chromolaena odorata) leaf meal (SWLM) on laying hens. Biochemical and haematological implication. Pakistan journal of nutrition 4(5): 333-341.
Banerjee, J. C. 2007. A text book of Animal Husbandry. Oxford and IBH publishing co. PVT. Ltd. New Delhi.

Esonu, B. O. 2000. Animal nutrition and feeding: A functional approach. Rukzed and RucksonsAssociates, Owerri, Nigeria.

Fasina O. O. and Ajibola, O. O. 1990. Development of equation for the yield of oil expressed $\mathrm{f} r$ o $\mathrm{m}$ conophor nut. Journal of Agricultural Engineerig Research. Volume 46: pages 45-53.

Igboeli, G. 2000. Animal production and Agricultural in the new millennium. Proc. Nig. Soc. Anim. Prod. 26; 1 3.

Jain, N. C. 1993. Essential of veterinary haematology, Lea and Febiger, Philedephia.

Kecceci, T., Oguz, H., Kurtoglu, V. and Demet, O. 1998. Effect of polyvinlpyrrodine, synthesis zeolite and bentonite on serum biochemical and haematological c haracter of broiler chickensduring aflatoxicosis. $B r$. Poult. Sci., 39: 152-158.

Maduike, F. N. and Ekenyem, B. U. 2001. Non ruminant livestock production in the tropics, Gutschuks graphics, Owerri, Nigeria; Pp 285.

Odunsi, A. A. 2002. Effect of feeding reject cashew kernel meal on pre and early-laying performance of pullets. Arch. Zootech., 51(196): 423-429.

Opara, C. C. 1996. Studies in the use of Alchorneacordifolialeaf meal as feed ingredients in poultry diets. MSc, thesis, Federal University of Technology, Owerri, Nigeria.

Sonaiya, E. B. 1990. The context and 


\section{Processing methods of Napoleona imperialis (Napoleons Hat)}

prospects for development of small holder rural poultry production in Africa. In proceedings international seminar on small holder rural poultry production. September 1992 Vol. 2 Pp. 684-687.

Uchegbu, M. C., Okoli, I. C., Etuk, E. B., Anyanwu, C. E. and Esonu, B. O. 2002. Preliminary studies on Napoleonaimperialis as livestock feed ingredient. Proximate composition.Proceedings of the $36^{\text {th }}$ Annual conference of the Agricultural Society of Nigeria, Futo, Owerri, October 20-24, Pp 422-421.

Uchegbu, M. C., Okoli, I. C., Anyanwu, C. E., Etuk, E. B., Esonu, B. O. and Udedibie, A. B. I. 2004. Performance carcass and organ characteristicsof finisher broiler fed graded levels of raw Napoleon imperialis seed meal. Livestock Research for Rural Development 16(6). Retreived September 1 2009,fromhttp://www.Irrd16/uche1 604.htm
Uko, O. J. and Kamalu, F. N. 2008. Trend of food production and efficiency of broiler production with raw or heat treated Neem kernel. Arch. Zootech 57(22): 489-496.

Udedibie, A. B. I. and Carlini, C. R. 1998. Brazillian Mucuna puriens seeds Vevet bean) lack haemagglutinating a c tivity. J.Agric. Food Chem.46:1450-1452

Received: $4^{\text {th }}$ November, 2017

Accepted: $17^{\text {th }}$ February, 2018 